\title{
ПИТАННЯ ПІДГОТОВКИ ТА ПРОВЕДЕННЯ ЛІЦЕНЗІЙНОГО ІСПИТУ «КРОК М. СЕСТРИНСЬКА СПРАВА»
}

\author{
В. І. Демиденко \\ Новгород-Сіверське медичне училище
}

У вступній частині статті визначено мету проведення ліцензійного тестування. Вказано основні види контролю знань, які використовують в медичному училищі. Викладено заходи, які вживають в навчальному закладі з метою підвищення якості освіти та підготовки до ліцензійного іспиту «Крок М. Сестринська справа».

\section{THE QUESTIONS OF THE PREPARATION AND CONDUCTING OF THE LICENSED EXAMINATION "KROK M. NURSING”}

\author{
V. I. Demydenko
}

\section{Novhorod-Siverskyi Medical School}

The introduction of the article outlines the aim of the licensed examination and the main types of academic performance rating, used in the medical school. The measures, taking for increasing the quality of education and for the preparation for the licensed examination "Krok M. Nursing” are described.

Вступ. На сучасному етапі розвитку медичної освіти основним завданням вищих навчальних закладів України є підготовка висококваліфікованих, конкурентоспроможних фахівців, які 6 відповідали загальноєвропейським стандартам [2]. Професійно компетентною вважається та медична сестра, яка вміє застосовувати знання з клінічного медсестринства при наданні медичних послуг і медичної допомоги та організаційно-управлінській діяльності. Тому Центр тестування при МОЗ України проводить перевірку відповідності професійної компетентності медичної сестри вимогам основних стандартів вищої освіти та іiї готовності здійснювати професійну діяльність шляхом проведення ліцензійного тестового іспиту «Крок М. Сестринська справа» [5].

Основна частина. Контроль або перевірка результатів навчання в нашому навчальному закладі $\epsilon$ обов'язковим компонентом навчального процесу і має місце на всіх стадіях підготовки медичних сестер. Головна функція перевірки результатів навчання полягає у визначенні знань іумінь студентів, оволодінні обов'язковим мінімумом змісту дисципліни [2].

У медичному училищі використовують такі види контролю: поточний, періодичний, підсумковий.

(c) В. І. Демиденко, 2019
Поточний контроль здійснюють під час проведення практичних, лабораторних та семінарських занять. Періодичний контроль проводять після засвоєння окремих тем, розділів. Підсумковий контроль включає семестровий контроль та державну атестацію студента й передбачає перевірку практичної майстерності з профільних дисциплін (виконання практичних навичок) і тестовий контроль [1].

Тестова перевірка, яку проводять під час навчання в медичному училищі, має ряд переваг перед традиційними формами і методами навчання, вона вписується в сучасні педагогічні концепції, дозволяє раціонально використовувати час занять, охопити більший об'єм змісту, швидко встановити зворотний зв'язок зі студентами і визначити результати засвоєння матеріалу, зосередити увагу на пропуски у знаннях і внести відповідні корективи. Тестова форма контролю забезпечує одночасну перевірку знань студентів всієї групи і формує в них мотивацію до більш якісної підготовки до занять [2].

Студенти медичного училища мають можливість підготуватись належним чином до ліцензійного тестування: під час лекцій, практичних занять, у вільний час в спеціально створених комп'ютерних класах. Тому в останні роки за результатами ліцензійного 
тестового іспиту «Крок М. Сестринська справа» Новгород-Сіверське медичне училище займало високі місця в рейтингу вищих медичних навчальних закладів I-II рівнів акредитації, за винятком 2018 р., де медичне училище зайняло низьке місце в рейтингу.

3 метою підвищення якості освіти та підготовки до складання ліцензійного іспиту «Крок М. Сестринська справа» навчальною частиною в 2018-2019 навчальному році проведено низку заходів: питання підготовки з аналізом результатів заслуховують на засіданнях випускаючих циклових комісій професійної та практичної підготовки щомісячно; розроблено та поширено серед студентів навчальні та контролюючі тестові програми в електронному варіанті та на паперових носіях; протягом навчального року відповідно до графіка проводять тестування студентів із подальшим аналізом результатів, що дає змогу випускникам адаптуватись до регламенту та вимог проведення ліцензійного іспиту, здійснюють заміри результатів підготовки, а також складають рейтинг підготовки студентів; за результатами проведених тестувань було виділено «групу ризику», яка не набрала достатню кількість правильних відповідей, дані про таких студентів передають випускаючим цикловим комісіям професійної та практичної підготовки для організації подальшої консультативної роботи 3

\section{СПИСОК ЛІТЕРАТУРИ}

1. Унгурян Л. М. Застосування тестової системи оцінки знань в навчальному процесі / Л. М. Унгурян, М. С. Образенко // Нові напрямки впровадження кредитно-модульної системи організації навчального процесу у вищих медичних і фармацевтичному навчальних закладах України III-IV рівнів акредитації : матеріали Всеукраїнської наукової навчально-методичної конференції. Тернопіль, 2011. - С. 148-149.

2. Гордійчук С. В. Впровадження системи підготовки студентів КВНЗ «Житомирський інститут медсестринства» до складання ліцензованих інтегрованих іспитів «Крок-М» та «Крок-Б» / С. В. Гордійчук // Вища освіта в медсестринстві: проблеми і перспективи : матеріали наук.-практ. конф. з міжнар. участю (Житомир, 1718 жовт. 2013 р.). - Житомир : ТОВ 505, 2013. - С. 29-31.

3. Терещенко А. О. Самостійна робота студентів як елемент підготовки до складання МЛІ «Крок-1» та «Крок-2» / ними та підвищення рівня вимог під час проведення поточних занять з метою активізації роботи з даним контингентом студентів; також навчальною частиною медичного училища складено графіки консультацій для студентів-випускників, які за результатами тестового контролю з профільних дисциплін не набирають відповідну кількість необхідних балів. Для таких студентів організовують і проводять індивідуальну роботу окремо [3].

Своєчасний аналіз успішності та заходи щодо ії покращання в цілому дають позитивні результати. Результати складання ліцензійного інтегрованого іспиту «Крок М» студентами спеціалізації «Сестринська справа» за 2019 р. становлять: тест - 88,3 \%, субтести - $з$ основ медсестринства - 92,6 \%, медсестринство у внутрішній медицині - 88,4\%, медсестринство в хірургії - 88,3 \%, медсестринство в педіатрії - 88,0 \%, медсестринство в акушерстві та гінекології - 88,4 \%.

Висновки. Проведення комплексної підготовки студентів до складання тестового ліцензійного іспиту «Крок М. Сестринська справа» сприяє підвищенню якості освіти з підготовки висококваліфікованих, конкурентоспроможних фахівців та формування професійної компетентності випускників згідно з вимогами Державних стандартів вищої освіти.

А. О. Терещенко, Ф. О. Ніколаева, В. О. Федоров // Самостійна робота студентів в умовах кредитно-модульної організації навчального процесу як засіб забезпечення якості вищої медичної освіти : матеріали XII навчальнометодичної конференції. - Харків, 2010. - С. 24-27.

4. Булах І. Є. Вимоги до рейтингової системи оцінювання підсумкових знань / І. Є. Булах, Л. М. Артемчук // Педагогіка і психологія професійної освіти. - 1998. - № 2. С. 97-100.

5. Досвід створення якісних тестових завдань для проведення медичного ліцензійного іспиту «Крок М. Сестринська справа» / Р. О. Сабадишин, В. І. Баб'як, В. М. Кірічек, О. В. Баб'як // Вища освіта в медсестринстві: проблеми і перспективи : тези доповідей Всеукраїнської науково-практичної конференції. - Житомир, 2011. 